\title{
An Analysis of Students' Speaking Anxiety in English Classroom at SMAN 2 Siak Hulu
}

\author{
Najiha $^{1]}$, Betty Sailun ${ }^{2]}$ \\ Universitas Islam Riau \\ E-mail: ${ }^{1]}$ najihanajiha787@gmail.com \\ ${ }^{2]}$ bettysailun@edu.uir.ac.id
}

\begin{abstract}
Many foreign language students are apprehensive about learning a new language in a certain situation. When they are asked to express their thoughts in front of their peers and lecturers, they appear to become more anxious. Then, when they talk in English, they never feel completely at ease. Consequently, the aim of this research is to determine the level of student speaking anxiety and to determine the dominant type of anxiety that occurs in English classroom. This research was conducted by using descriptive quantitative study. The research participants were the third-grade students of SMAN 2 Siak Hulu of academic year 2020/2021. The total of students was 34 students. Then, the researchers obtained the data through questionnaires. The result of this research showed that most experienced level of speaking anxiety in the third-grade students was Mildly Anxious. Additionally, based on FLCAS, there are 3 types of speaking anxiety students experienced in the classroom was negative evaluation, followed by test anxiety and communication apprehension. In this case, the researchers found that "Communication Apprehension" was the main factor causing around $27(79 \%)$ students to feel nervous, followed by 23 (68\% students with "Fear of Negative Evaluation" factors, and the lowest factor for $22(65 \%)$ students was "Test Anxiety". Therefore, the third-grade students of SMAN2 Siak Hulu were categorized at the Mildly Anxious level of speaking anxiety in the English classroom.
\end{abstract}

Keywords: Speaking Anxiety, English Classroom, Senior High School

\section{Analisis Kecemasan Berbicara Siswa di Kelas Bahasa Inggris di SMAN 2 Siak Hulu}

\begin{abstract}
Abstrak
Banyak siswa merasa khawatir ketika belajar bahasa baru dalam situasi tertentu. Ketika siswa diminta untuk mengungkapkan pendapat di depan teman dan dosen, mereka tampak lebih cemas. Kemudian, ketika mereka berbicara dalam bahasa Inggris, mereka tidak pernah merasa benar-benar nyaman. Oleh karena itu, tujuan penelitian ini adalah untuk menentukan tingkat kecemasan berbicara siswa dan untuk menentukan jenis kecemasan dominan yang terjadi di kelas Bahasa Inggris. Penelitian ini dilakukan dengan menggunakan studi kuantitatif deskriptif. Peserta penelitian adalah siswa kelas 3 SMAN 2 Siak Hulu tahun akademik 2020/2021.Total siswa adalah 34 siswa. Kemudian, peneliti memperoleh data melalui kuesioner. Hasil penelitian ini menunjukkan bahwa tingkat kecemasan berbicara yang paling berpengalaman pada siswa kelas tiga adalah Mildly Anxious. Selain itu, berdasarkan FLCAS, ada 3 jenis kecemasan berbicara yang dialami siswa di kelas adalah evaluasi negatif, diikuti oleh kecemasan tes dan kekhawatiran
\end{abstract}


komunikasi. Dalam hal ini, penulis menemukan bahwa "Kekhawatiran Komunikasi" adalah faktor utama yang menyebabkan sekitar 27 (79\%) siswa merasa gugup, diikuti oleh 23 (68\%) siswa dengan faktor "Takut Evaluasi Negatif", dan faktor terendah untuk 22 (65\%) siswa adalah "Test Anxiety". Oleh karena itu, siswa kelas 3 SMAN2 Siak Hulu dikategorikan pada tingkat kecemasan berbicara ringan dalam kelas bahasa Inggris.

Kata Kunci: Kecemasan Berbicara, Kelas Bahasa Inggris, Sekolah Menengah Atas

\section{INTRODUCTION}

One of the four essential abilities in language acquisition is speaking, because speech is a tool that people use to communicate with one another. Though speaking is challenging, everyone should do it since it allows them to convey their thoughts and ideas directly. When people may communicate directly by speaking and others can offer and receive replies in a short amount of time. As a result, humans cannot survive without engaging in some form of communication with others.

Furthermore, while speaking is an important part of language acquisition, it is still difficult for learners to become proficient in English and even master it. Students must be able to communicate well in English. Many individuals, on the other hand, demonstrate their incompetence and frequently admit that they do not wish to speak English. It occurs because some students are uncomfortable speaking in front of others. Other factors that students experience include shame, fear of making mistakes, anxiousness, and anxiety when speaking English.

Anxiety in speaking is incredibly common. If a student speaks in front of many people, it feels natural they are anxious, unconfident, shy and nervous. Because every student has different psychological condition, some of them can speak confidently in front of the class, and some of them unable to speak English because they are shy and nervous. Nevertheless, anxiety in speaking English can weaken and affect students' adaption to the target environment and ultimately the achievement of their educational objectives. However, anxiety does not need to be eliminated and does not even have to be eliminated. Therefore, it is better to manage the fear and then make it the driving force (positive energy) used in preparation for speaking.

Based on the observation at the third-grade students of SMAN 2 Siak Hulu, the researchers found some problems. Firstly, some of the students at this school are less confident, because they have limited knowledge on pronunciation. Thus, they never feel quite sure of their self when they are speaking in English.

Secondly, students' fear of negative evaluations. Students always think that their friends are better at speaking English. So, students think if they make mistakes in speaking English, their friends will laugh at them. Therefore, students who lack the courage to speak out for fear of being wrong, it is impossible for them to convey their ideas directly, because they feel not confidence and shy to speak English.

Thirdly, the students feel anxiety in test. The students usually worry about the consequences of failing English class. Because, they feel nervous when they don't understand every word that is said by the English teacher and they have to speak without preparation. So, the students will be panic when they know that they name going to be called on in English class. The objectives of this research are to find out the levels of students speaking anxiety in the English 
classroom and what kind of anxiety occurred in the English classroom.

According to (Leong \& Ahmadi, 2017), speaking is an interactive process of constructing meaning that involves producing and receiving and processing information It means that speaking activity the speakers must use oral language well to transfer the information to order people (Komariah et al, 2020). Meanwhile, Schmitt (2012) in (Derakhshan, Atefeh and Fatima, 2016) present that speaking is a part of daily life that everyone should develop in subtle and detailed language. Then, speaking is a crucial skill for English students to learn at the university level since it is necessary for them to enhance their capacity to communicate verbally by expressing their thoughts in a real-life setting (Sailun \& Idayani, 2018).

Speaking, in a summary, is the act of communicating with others via the use of words. People all around the globe share information and let everyone know what the speaker is thinking about by speaking, which indicates that speaking is a common activity in daily life and that communication through speaking entails interaction between the speaker and the listener. Then, when conversing with others, some individuals were nervous and anxious.

Anxiety is one of the most wellknown psychiatric illnesses. Anxiety is described as a fearful, worried, stressed, or tense sensation. Furthermore, anxiety is normal in speaking. It is a basic human emotion that has some developmentally predictable onsets, occurrences, and trajectories (Huberty, 2012). In addition, when the students are worried while speaking, their mind appears to cause significant negative self-talking, and it is something that can hinder students' performance and achievement in language acquisition.

\section{The Nature of Anxiety}

Anxiety is one of the psychological disorders which are most well-known. In general, anxiety arises as a reaction to a given situation from the human body. Anxiety is generally defined as a feeling of fear, nervous, stress, or tension. There are several meanings of anxiety found by the researchers. According to Mohtasham \& Farnia (2017), anxiety is that state of an individual when he/she feels "uneasiness, frustration, self-doubt, apprehension, or worry" similar to any other specific anxiety.

Furthermore, (Khoshlessan \& Das, 2017) stated that student anxiety is the feelings, thoughts, and experiences that create an apprehension level during the study process and affect the students' academic performance. Then, according to Sutarsyah (2017) state that anxiety (also called angst or worry) is a psychological and physiological state characterized by somatic, emotional, cognitive, and behavioral components. It is the displeasing feeling of fear and concern.

\section{Types of Anxiety}

Anxiety has been categorized into three aspects: 1) trait anxiety, 2) state anxiety, and 3) situation- specific anxiety (Oteir \& Al-Otaibi, 2019); (Spilberger, in Safaria \& Saputra, 2012); (Mitha, et al, 2018) state that trait anxiety is a tendency in a person to feel threatened by a number of conditions those are actually harmless. Anxiety in this category is more due to the personality of the individual does have potential anxiety than other individuals. In other words, trait anxiety suggests a person's propensity be nervous or anxious regardless of the situation to which he or she is exposed.

Furthermore, Mitha et al (2018) also mention that state anxiety is the temporary emotional state and condition 
in a person characterized by a tense and anxious feeling that is felt consciously and subjective and leaves the activity of the autonomic nervous system, as a condition related to special environmental situations. On the other hand, when the situation is unsafe, it is a situationsensitive fear that vanishes.

Finally, when a nervous individual is confronted with real-life speaking situations, he risks speaking too fast, missing words, murmuring, unconsciously, reading the note, and failing to make eye contact with the audience, among other things. An nervous individual frequently performs badly in speaking class exercises as a result of these variables.

Hereafter, situation-specific anxiety can be considered to be the probability of becoming anxious in a particular type of situation, such as during test (labeled as "test anxiety"), when solving mathematics problems (math anxiety"), or when speaking a second language ("language anxiety"). Language anxiety is recognized as a construct of situation-specific anxiety, mainly independent of the other types of anxiety (Horwitz et al in Akkakoson, 2016).

Feeling anxious is an indication that he or she has courage to be successful language learner. In this sense, anxiety can be considered as positive language learning variable. Foreign language students' positive expectations for their own performance are important predictors of their future success (Sutarsyah, 2017).

\section{The Foreign Language Classroom Anxiety Scale (FLCAS)}

The Foreign Language Classroom Anxiety Scale (FLCAS) was developed by Horwitz and Cope in Mitha et al, 2018) as the most widely used method for measuring FLA. The FLCAS is composed of 33 items. This has two types of positive and negative statements. One of these can be the answers to each item: strongly agree, agree, neither agree nor agree, disagree, and strongly disagree. For each item a score was given ranging from 5 for strongly agree; 4 for agree; 3 for neither agree nor agree; 2 for disagree; 1 for strongly disagree.

Foreign language anxiety can be related to the following: communication apprehension (the fear of communicating with other), test anxiety (the fear of exams, quizzes, and other activities used to evaluate one's competence) and the fear of negative evaluation (the worry about how others view the speaker) (Meily \& Nurlita, 2018).

\section{a. Communication Apprehension}

Communication apprehension was a type of shyness characterized by fear of communicating with people. Suleimenova in Neman \& Ganap, 2018) noted that "anxious student may not be able to take in a spoken dialogue fast enough because anxiety interferes, with their ability to process information". Someone with an apprehension for communication get difficulties to speak in groups or in front of many people or even listen to the message being spoken. Apprehension of communicating can be triggered by need to construct a language structure in a language which has not been completely learned. The inability to express you yourself in the right way can cause frustration in classes foreign languages.

\section{b. Test Anxiety}

(Horwitz \& Young in Mohtasham \& Farnia, 2017) defined test anxiety as the fear of failing in tests and a displeasing experience that learners hold either consciously or unconsciously in many situations. Students with test anxiety encounter learning problems and take material during the test, which contributes to poor test results. Students 
who are tested in a foreign language class may face serious problems. Because tests and quizzes are common and even the brightest students who are prepared also make mistakes. Oral tests have the potential of provoking both test-and oral communication anxiety simultaneously in susceptible students.

\section{c. Fear of negative evaluation}

Negative evaluation is broader in scope because it is not limited to testtaking situation and it may occur in any social, evaluate situation such as interviewing for a job or speaking in English or foreign language. According to (Lian \& Budin, 2014), they stated that "generally they felt they were being judged and cast in poor light by teacher and peers". In other words, the students become a passive learner in learning English because of other student evaluation and teacher evaluation (Meily \& Nurlita, 2018).

\section{METHOD}

This research used the quantitative descriptive method. Mitha et al (2018) states that quantitative descriptive designed in qualitative research whether it is not the real qualitative research as the construction of the content is influenced by quantitative data. This research was conducted to the third students of SMAN 2 Siak Hulu. The location in this research at SMAN 2 Siak Hulu in 2020/2021 academic year, which located in $\mathrm{Jl}$. Kubang Raya No. 14, Kubang Jaya, Siak Hulu, Kampar. The number of the participants in the class is 34 consisting of 14 males and 20 females.

The FLCAS has been the most widely used instrument to measure foreign language learners' general anxiety in foreign language classrooms. This scale provided five responses ranging from "Strongly Agree (SA)", "Agree (A)", "Neither Agree nor Disagree (NA)",
"Disagree (D)", and "Strongly Disagree (SD)". FLCAS contains two types of positive and negative statements. The questionnaire includes positive statements in numbers $2,5,8,11,14,18,22,28,32$. However, negative statements are in numbers $1,3,4,6,7,9,10,12,13,15$, $16,17,19,20,21,23,24,25,26,27,29$, $30,31,33$.

Interview used as secondary data. The purpose of this interview is to get more data related to this research. Indepth interview is a process to obtain information for the purpose of research by face questioning between the interviewer and informant or interviewee, with or without the use of an interview guide.

The researchers collected data online by using google forms to make it easier for students to answer FLCAS Questionnaire. The students only need to open the link that has been sent by the researchers, and after that the students can fill out the questionnaire. The researchers analyzed and interpreted the data, based on the theory, after all the data were collected. Futhermore, the researchers also conducted online interviews with several students via WhatsApp.

Next, the data were measured by using scoring scale table for calculating the anxiety level of the students using FLCAS. After the researchers have identified the product of the anxiety level of each student, it will be classified into some levels starting from "Very Relaxed", "Relaxed", "Mildly Anxious", "Anxious", and "Very Anxious". On the other hand, the scoring table adopted from Oetting's Scale cited in Mayangta (2013), consisting of 40 items with answers ranging from $1-5$ to 200 overall. The following table represents the score for every level of anxiety. 


\section{FINDINGS AND DISCUSSION \\ A. Levels of Speaking Anxiety in English Classroom}

Horwitz et al have developed the "Foreign Language Classroom Anxiety Scale" (FLCAS) to measure students' levels of anxiety. The measure has scored 33 items on a 5-point Likert scale ranging from strongly agree, agree, neither agree nor disagree, disagree, and strongly disagree. The participants in this study, which are all the third MIPA 2 grades in SMAN 2 Siak Hulu in the academic year 2020/2021 were answered the questionnaire in complete.

There are 34 students in one class who participated to fill out the questionnaire, consisting of 15 male and 19 female. Then, there are 33 questionnaire items that had to be filled out by students. Students answer each item by choosing the answer based on how they feel in study English. The answers included "Strongly Agree (SA)," "Agree (A)," "Neither Agree nor Agree (NA)," "Disagree (D)," and "Strongly Disagree (SD)." Thus, the following is an analysis of the students' preference percentage.

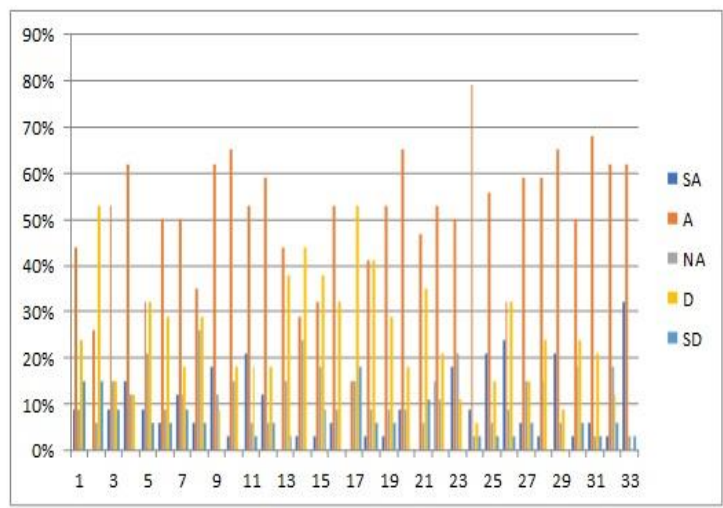

Figure 1. The percentage of students' preference

The results indicate that high and

low total score percentage of all statements of FLCAS, based on the figure and table. There are 34 participants who have different responses to each answer. The researchers consider the highest total in statement number 24 (I feel very selfconscious about speaking the English in front of other students) with 79\% of respondents. Even the researcher see homogeneity in the same statement number 10 "I worry about the consequences of failing my English class."; statement number 11 "I don't understand why some people get so upset over English classes."; statement number 13 "It embarrasses me to volunteer answers in my English class."; statement number 14 "I would not be nervous speaking the English with native speaker."; statement number 15 "I get upset when I don't understand what the teacher is correcting."; statement number 18 "I feel confident when I speak in English class."; statement number 19 "I am afraid that my English teacher is ready to correct every mistake I make."; statement number 24 "I feel very selfconscious about speaking the English in front of other students."; statement number 25 "English class moves so quickly I worry about getting left behind."; statement number 30 "I feel overwhelmed by the number of rules you have to learn to speak English."; statement number $31 \mathrm{I}$ am afraid that the other students will laugh at me when I speak the English."; statement number 32 "I would probably feel comfortable around native speakers of the English."; statement number 33 "I get nervous when the English teacher asks questions which I haven't prepared in advance". With 3\% of answers ( 1 student). To determine students' level of anxiety while speaking, the researcher assesses and categorizes each student based on their responses in the FLCAS questionnaire, as shown in Table 1. 
Table 1. Result of foreign language classroom anxiety scale

\begin{tabular}{ccc}
\hline Range & Level & Result \\
\hline $124-165$ & Very Anxious & 6 students (18\%) \\
$108-123$ & Anxious & 11 students (32\%) \\
$87-107$ & Mildly anxious & 13 students (38\%) \\
$66-86$ & Relaxed & 4 students (12\%) \\
$33-65$ & Very Relaxed & 0 students (0\%) \\
\hline
\end{tabular}

The Table 1 shows that from 34 students, $6(18 \%)$ experienced a "Very Anxious" level. Then, 13 (38\%) were at a "Mildly Anxious" level. This can be a normal condition because many people often feel anxious or nervous when they have to do something in front of others, and only 4 students (12\%) at the "Relaxed" level that indicate they have no problem with their anxiety level.

\section{B. Dominant Type of Anxiety that \\ Occurred in English Classroom}

There are 3 types of classroom anxiety namely, communication apprehension, test anxiety, and fear of negative evaluation.

\section{Students' Communication Apprehension}

Based on the Table 2, it can be seen that most of students don't understand some of words that the English teacher say. So the students can not get what their teacher meant. Besides, some of the students are not confident to speak English in front of the others. Because, they will get nervous and confused when they are speaking in their English class, and there are also some students who panic if they have to speak without prior preparation. Moreover, the information from the Table 2 can be seen as follows.
Table 2. The percentage of students' communication apprehension

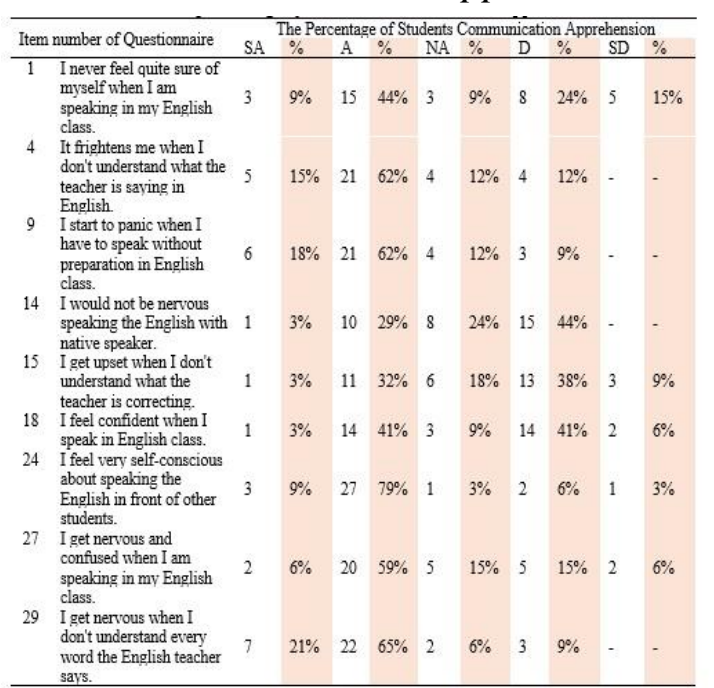

The Figure 2 is an overview summary of the students' communication apprehension as follows.

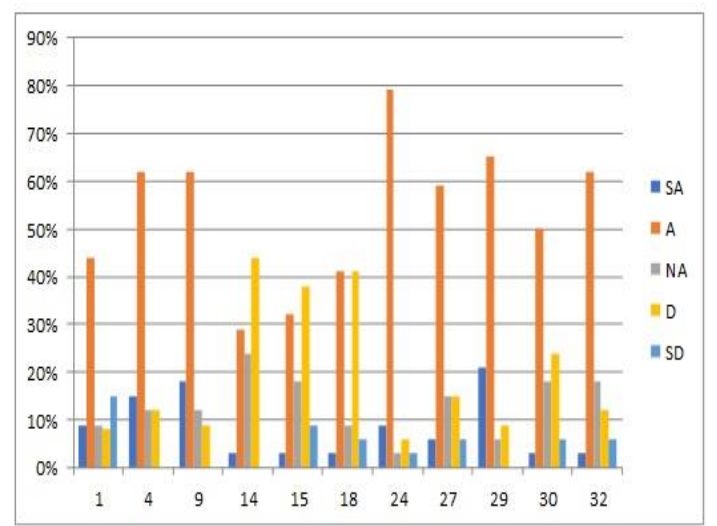

Figure 2. The percentage of students' communication apprehension.

Based on the Figure 2, the results show the highest total is in statement number 24 (I feel very self-conscious about speaking the English in front of other students) with $79 \%$ of respondents (27 students). The researchers may therefore infer that the students do not want to speakd English because they are ashamed, anxious, and uncofident when they are in front of the class. 


\section{Students' Test Anxiety}

Test anxiety is defined as a distressing sensation that learners have in various settings, either consciously or unconsciously. Based on the table 3, there are about $53 \%$ of students who feel scared if their names are called even if they are ready for English class, they feel nervous. Then, they can nervous and forget things that they know. The students feel more tense in English class than the other classes. Because, worry about the consequences of failing in English class.

Table 3. The percentage of students' test

\begin{tabular}{|c|c|c|c|c|c|c|c|c|c|c|c|}
\hline \multirow{2}{*}{\multicolumn{2}{|c|}{ Item Number of Queationnaire }} & \multicolumn{10}{|c|}{ The Percentage of Students Test Anviety } \\
\hline & & SA & $\%$ & $A$ & $\%$ & $\mathrm{NA}$ & $\%$ & $\mathrm{D}$ & $\%$ & SD & $\%$ \\
\hline 3 & $\begin{array}{l}\text { I tremble when I know } \\
\text { that Im going to be called } \\
\text { on in English class. }\end{array}$ & 3 & $9 \%$ & 18 & $53 \%$ & 5 & $15 \%$ & 5 & $15 \%$ & 3 & $9 \%$ \\
\hline 5 & $\begin{array}{l}\text { It wouldin't bother me at } \\
\text { all to take more English } \\
\text { classes. }\end{array}$ & 3 & $9 \%$ & 11 & $32 \%$ & 7 & $21 \%$ & 11 & $32 \%$ & 2 & $6 \%$ \\
\hline 6 & $\begin{array}{l}\text { During English class, I } \\
\text { find myself thinking about } \\
\text { things that have nothing to } \\
\text { do with the course. }\end{array}$ & 2 & $6 \%$ & 17 & $50 \%$ & 3 & $9 \%$ & 10 & $29 \%$ & 2 & $6 \%$ \\
\hline 8 & $\begin{array}{l}\text { I am usually at ease during } \\
\text { tests in my English class. }\end{array}$ & 2 & $6 \%$ & 12 & $35 \%$ & 9 & $26 \%$ & 10 & $29 \%$ & 2 & $6 \%$ \\
\hline 10 & $\begin{array}{l}\text { I wory about the } \\
\text { consequences of failing } \\
\text { my English class. }\end{array}$ & 1 & $3 \%$ & 22 & $65 \%$ & 5 & $15 \%$ & 6 & $18 \%$ & - & - \\
\hline 11 & $\begin{array}{l}\text { I don't understand why } \\
\text { some people get so upset } \\
\text { over English classes. }\end{array}$ & 7 & $21 \%$ & 18 & $53 \%$ & 2 & $6 \%$ & 6 & $18 \%$ & 1 & $3 \%$ \\
\hline 12 & $\begin{array}{l}\text { In English class, I can get } \\
\text { so vervous I forget things } \\
\text { I know. }\end{array}$ & 4 & $12 \%$ & 20 & $59 \%$ & 2 & $6 \%$ & 6 & $18 \%$ & 2 & $6 \%$ \\
\hline 16 & $\begin{array}{l}\text { Even if I am well prepared } \\
\text { for English class, I feel } \\
\text { enziouss about it. }\end{array}$ & 2 & $6 \%$ & 18 & $53 \%$ & 3 & $9 \%$ & 11 & $32 \%$ & - & - \\
\hline 17 & $\begin{array}{l}\text { I often feel like not going } \\
\text { to my English class. }\end{array}$ & - & $\cdot$ & 5 & $15 \%$ & 5 & $15 \%$ & 18 & $53 \%$ & 6 & $18 \%$ \\
\hline 20 & $\begin{array}{l}\text { I can feel my heart } \\
\text { pounding when I'm going } \\
\text { to be called on in English } \\
\text { class. }\end{array}$ & 3 & $9 \%$ & 22 & $65 \%$ & 3 & $9 \%$ & 6 & $18 \%$ & - & - \\
\hline 21 & $\begin{array}{l}\text { The more I study for an } \\
\text { Engliah test, the more } \\
\text { confused I get. }\end{array}$ & $\cdot$ & - & 16 & $47 \%$ & 2 & $6 \%$ & 12 & $35 \%$ & 4 & $11 \%$ \\
\hline 22 & $\begin{array}{l}\text { I don't feel pressure to } \\
\text { prepare very well for } \\
\text { English class. }\end{array}$ & 5 & $15 \%$ & 18 & $53 \%$ & 4 & $11 \%$ & 7 & $21 \%$ & - & - \\
\hline 25 & $\begin{array}{l}\text { Engliah class moves so } \\
\text { quickly I worry about } \\
\text { getting left behind. }\end{array}$ & 7 & $21 \%$ & 19 & $56 \%$ & 2 & $6 \%$ & 5 & $15 \%$ & 1 & $3 \%$ \\
\hline 26 & $\begin{array}{l}\text { If feel more tense and } \\
\text { nervous in my English } \\
\text { class than in my other } \\
\text { classes. }\end{array}$ & 8 & $24 \%$ & 11 & $32 \%$ & 3 & $9 \%$ & 11 & $32 \%$ & 1 & $3 \%$ \\
\hline 28 & $\begin{array}{l}\text { When I'm on my way to } \\
\text { Engliah class, I feel very } \\
\text { gure and relared. }\end{array}$ & 1 & $3 \%$ & 20 & $59 \%$ & 5 & $15 \%$ & 8 & $24 \%$ & - & - \\
\hline
\end{tabular}

The following is an overview summary of the students' test anxiety based on the above table description.

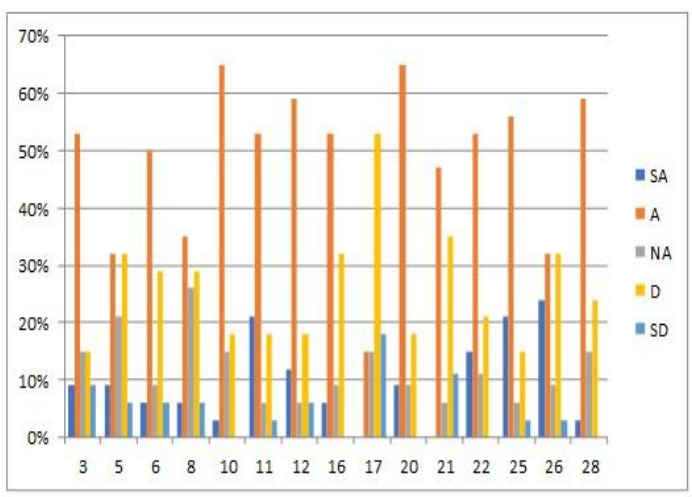

Figure 3. The percentage of students' test anxiety

Based on the Figure 3, the researchers found that the homogenity that appears is in statements number 10 and 20. "I worry about the consequences of failing my English class"; "I can feel my heart pounding when I'm going to be called on in English class" with 65\% of respondents (22 students). The researchers can conclude that students feel anxious when test anxiety, it shown by number 10 "I worry about the consequences of failing my English class" by which "agree" it is selected by 22 students so that more than half the students feel anxiety during test, and added by statement number 20 "I can feel my heart pounding when I'm going to be called on in English class", which means that students are always nervous even though well prepared in English class.

\section{The Students' Fear of Negative Evaluation}

Negative evaluation has a larger reach than positive evaluation since it is not restricted to test-taking situations and may occur in any social, evaluative setting. The table 4 showed the result of students fear of negative evaluation. There are 17 students (50\%) always afraid if their friends will laugh at them when they speak English, because they think that their friends are better at speaking English. It means that they are 
not confident. The students feel nervous when the English teacher asks them questions. Then, they also afraid that their teacher will correct every mistake they make.

Table 4. The percentage of students' fear of negative evaluation

\begin{tabular}{|c|c|c|c|c|c|c|c|c|c|c|c|}
\hline \multirow{2}{*}{\multicolumn{2}{|c|}{ Item Number of Questionnaire }} & \multicolumn{10}{|c|}{ The Percentage of Students Fear of Negative Evaluation } \\
\hline & & SA & $\%$ & A & $\%$ & NA & $\%$ & D & $\%$ & SD & $\%$ \\
\hline 2 & $\begin{array}{l}\text { I don't worry about making } \\
\text { mistakes in English class. }\end{array}$ & . & - & 9 & $26 \%$ & 2 & $6 \%$ & 18 & $53 \%$ & 5 & $15 \%$ \\
\hline 7 & $\begin{array}{l}\text { I keep thinking that the other } \\
\text { students are better at English } \\
\text { than I am. }\end{array}$ & 4 & $12 \%$ & 17 & $50 \%$ & 4 & $12 \%$ & 0 & $18 \%$ & 3 & $9 \%$ \\
\hline 13 & $\begin{array}{l}\text { It embarrasses me to volunteer } \\
\text { answers in my English class. }\end{array}$ & . & - & 15 & $44 \%$ & 5 & $15 \%$ & 13 & $38 \%$ & 1 & $3 \%$ \\
\hline 19 & $\begin{array}{l}\text { I am afraid that my English } \\
\text { teacher is ready to correct every } \\
\text { mistake I make. }\end{array}$ & 1 & $3 \%$ & 18 & $53 \%$ & 3 & $9 \%$ & 10 & $29 \%$ & 2 & $6 \%$ \\
\hline 23 & $\begin{array}{l}\text { I always feel that the other } \\
\text { students speak the English } \\
\text { better than I do. }\end{array}$ & 6 & $18 \%$ & 17 & $50 \%$ & 7 & $21 \%$ & 4 & $11 \%$ & - & - \\
\hline 31 & $\begin{array}{l}\text { I am afraid that the other } \\
\text { students will laugh at me when I } \\
\text { speak the English. }\end{array}$ & I 2 & $6 \%$ & 23 & $68 \%$ & 1 & $3 \%$ & 7 & $21 \%$ & 1 & $3 \%$ \\
\hline 33 & $\begin{array}{l}\text { I get nerrous when the English } \\
\text { teacher asks questions which I } \\
\text { haven't prepared in advance. }\end{array}$ & 11 & $32 \%$ & 21 & $62 \%$ & 1 & $3 \%$ & . & . & 1 & $3 \%$ \\
\hline
\end{tabular}

The following is an overview summary of the students' fear of negative evaluation.

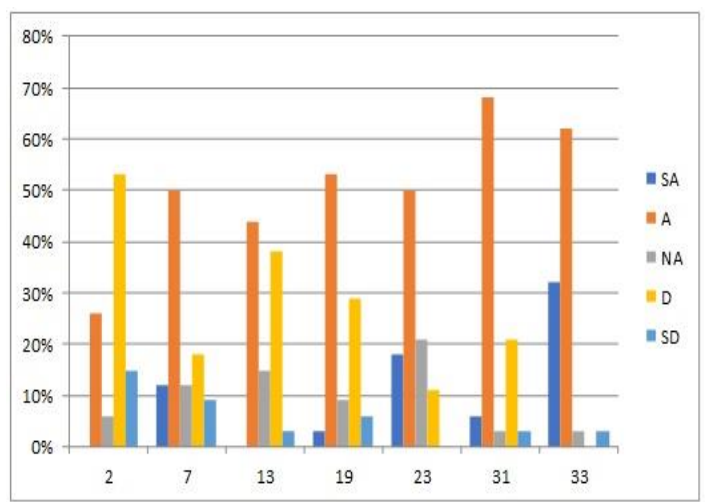

Figure 4. The percentage of students' fear of negative evaluation.

Based on the Figure 4, the results show the highest total is in statement number 31 "I am afraid that the other students will laugh at me when I speak the English" by which "agree" with total of 23 students. So it can be concluded that more than half the students or $68 \%$ of the paticipants are afraid of making mistakes, especially in oral pronunciation and communication, because they are affraid of negative evaluation from their friends or teachers.

In this case, the researchers found that "Communication Apprehension" was the main factor causing around 27 (79\%) students to feel nervous, followed by 23 (68\% students with "Fear of Negative Evaluation" factors, and the lowest factor for $22(65 \%)$ students was "Test Anxiety".

The finding of the research also supported from previous research have done from another researcher. Firstly, study from Kurniawanti (2017) said that from 90 learners majoring English Education Department of UIN Alauddin Makassar in the second semester mostly have medium speaking anxiety level. Secondly, the research by Abdillah (2018). This study is to investigate foreign language anxiety of EFL junior secondary school students at the 8th grade of SMPN 16 Semarang. The study results showed that they are internal factors (attitude, speaking in front of the class, laughing at peers, nonsensical feedback, student opinions about speaking English, lack of preparation), and external factors (teacher temperament, school setting, family environment). The last study from Isnaini (2018), the results revealed that the students' speaking anxiety factor in English as a foreign language (EFL) was: felt self-prediction to fear, unreasonable confidence, sensitivity to danger, sensitivity to anxiety, false body signal attribution, low self-efficacy. Second, the causes of the student's speaking anxiety those students were unconfident in speaking English fear of making mistakes while speaking, anxiety while the teacher asked to speak up, and shyness in performing in front of the class.

\section{CONCLUSION}

Based on the study, the researchers may conclude as follows. 
The results of questionnaire show that many students are at the "Mildly Anxious" level and no student with the "Very Relaxed" level. There are 6 (18\%) students experiencing the level of "Very Anxious," 11 (32\%) students at the level of "Anxious," 13 (38\%) students at the level of "Mildly Anxious," and 4 (12\%) students at the level of "Relaxed".

The result of interview shows that the students who the researchers have interviewed said that they are not confidence when they are speaking English. Because they are thinking that their friends are better in speaking English than them. Furthermore, the students afraid make a mistake especially in grammar and pronunciation. Then, all of students fear of teacher evaluation, and sometimes they feel afraid when the test or exam will be held.

Based on the results, each students certainly have feeling of anxiety at the different levels. For students whose high anxiety scale results need to reduce a little more relaxed. When in class, students also do not mock or laugh at each other when their friends make mistakes, but try to keep supporting and motivating them not to give up in learning. Students must realize that making mistakes when in an English language class is the normal thing, so it can be as a learning to be better in the future.

After conducting this research, the researcher made some suggestions. Those suggestions can consider by the students, teachers/lecturers, and the future researcher.

1. For Students

Based on the results, each students certainly have feeling of anxiety at the different levels. For students whose high anxiety scale results need to reduce a little more relaxed. When in class, students also do not mock or laugh at each other when their friends make mistakes, but try to keep supporting and motivating them not to give up in learning. Students must realize that making mistakes when in an English language class is the normal, so it can be as a learning to be better in the future.

2. For Teachers/Lecturers

The teachers or lecturers need to consider any fear that his students feel to overcome the student's anxiety in speaking skills. After that, the teacher/lecturer can make the class atmosphere cheerful so that a positive mood will appear. The students who feel happy and not nervous will learn comfortable. The teacher/ lecturer can insert humor or motivational words so as to make the class atmosphere relaxed and can reduce student's anxiety.

3. For Future Researcher

The researchers hope that the future researcher will be able to conduct better research about speaking anxiety in English classroom and improve the research with other skills such as reading, writing, and listening.

\section{REFERENCES}

Abdillah, Vera. (2018). Students' Anxiety Factors in Speaking English (A Case Study at the 8th Grade of SMP $N 16$ Semarang) in the Academic Year of 2016/2017. Education and Teacher Training Faculty. Universitas Islam Negeri Walisongo Semarang.

Akkakoson, Songyut. (2016). Speaking Anxiety in English Conversation Classrooms Among Thai Students. Journal of Learning and Instruction. 13 (1), 63-82.

Derakhshan, Ali., Atefah Nadi Khalili., \&

Fatima Beheshti. (2016).

Developing EFL Learner's Speaking Ability, Accuracy and Fluency. English Language And Literature Studies. 6 (2).

Huberty, Thomas J. (2012). Anxiety and Depression in Children and 
Adolescents Assessment, Intervention, and Prevention. New York: Springer Science and Business Media.

Isnaini, Nur. (2018). An Analysis of Students' Speaking Anxiety Students of English Foreign Language (EFL) at the Fifth Semester English Department of UIN Raden Intan Lampung Academic Year of 2018/2019. Tarbiyah and Teacher Training Faculty. Universitas Islam Negeri Raden Intan Lampung.

Kurniawanti. S.T. (2017). A Study of Speaking Class Anxiety of the Second Semester Students in English Education Department at UIN Alauddin Makassar. English Education Department Tarbiyah and Teaching Science Faculty. Universitas Islam Negeri Alauddin Makassar.

Khoshlessan, R., \& Das, K. P. (2017). Analyzing International Students' Study Anxiety in Higher Education. Journal of International Students, 7 (2), 311-328.

Komariah, E., Erdiana, N., \& Mutia, T. (2020). Communication strategies used by EFL students in classroom speaking activities. International Journal of Language Studies, 14(3), 27-46.

Leong, L., \& Ahmadi, S.M. (2017). An analysis of factors influencing learners' English speaking skill. International Journal of Research in English Education (IJREE) 2 (1), 35.

Lian, H. L. \& Budin, Mardziah. (2014). Investigating the Relationship between English Language Anxiety and the Achievement of School based Oral English Test among Malaysian Form Four Students. International Journal of Learning, Teaching and Educational Research. 2 (1), 67-79.
Mayangta, Tesalonika. (2013). Students' Speaking Anxiety in an EFL Classroom. Research Paper, Universitas Pendidikan Indonesia. 28.

Mitha, W.D., Amri, Z., Narius, D. (2018). An analysis of students' speaking anxiety faced by the fourth semester students of EEnglish education study program of English Department of Universitas Negeri Padang. Journal of English Language Teaching, 7(3), 467.

Mohtasham L, \& Farnia M. (2017). English Speaking Anxiety: A Study of the Effect of Gender on Iranian EFL University Students' Perceptions. International Journal of Research in English Education (IJREE). 2017; 2 (4).

Neman, M.I.E \& Ganap, N.L. (2018). Student Anxiety in Learning English as a Foreign Language (EFL). Proceedings of the $65^{\text {th }}$ TEFLIN International Conference, Vol 65, No 2.

Oteir, I. N., \& Al-Otaibi, A. N. (2019). Foreign Language Anxiety: A Systematic Review. Arab World English Journal, 10 (3) 309-317.

Safaria, T. \& Saputra, E.N. (2012). Manajemen Emosi: Sebuah Panduan Cerdas Bagaimana Mengelola Emosi Positif Dalam Hidup Anda. Jakarta: Bumi Aksara.

Sailun, B. \& Idayani, A. (2018). The Effect of Ted Talks Video Towards Students' Speaking Ability at English Study Program of Teacher Training and Education Faculty, Universitas Islam Riau. Persfektif Pendidikan dan Keguruan: 9 (1), 65-74.

Schmitt, R. (2012). Applied Linguistics. In A. Burns \& B. Seidhofer (Eds.), Speaking and Pronunciation (pp.197-199). London: Great Britain Press. 
Sutarsyah, C. (2017). An Analysis Of Student's Speaking Anxiety and its Effect on Speaking Performance. Indonesian Journal of English Language Teaching And Applied Linguistics (IJETAL). 1(2). 